\title{
A Context of Risk: \\ Uncovering the Lived Experiences of Chin Refugee Women Negotiating a Livelihood in Delhi
}

\author{
PAULA JOPS, CAROLINE LENETTE, AND JAN BRECKENRIDGE
}

\begin{abstract}
In India, the livelihood spaces that refugee women from Chin State, Burma, have carved for themselves in their country of first asylum remain relatively unexplored. This article focuses on Chin refugee women's pursuit of livelihood in Delhi in 2012-13. The concept of "livelihood" is a starting point to better understand the women's work experiences and explore the associated risks affecting their well-being. Emerging findings indicate that pervasive sexual harassment and discrimination, inside and outside of work contexts and a constant sense of livelihood insecurity severely affect the health and well-being of these women and contribute to diminished hopes for a future in Delhi.
\end{abstract}

\section{Résumé}

En Inde, les contextes que les femmes réfugiées originaires de l'État Chin, en Birmanie, se sont façonnés afin d'assurer des moyens de subsistance dans leur pays de premier asile demeurent relativement peu étudiés. Cet article est axé sur la quête de moyens de subsistance de la part des femmes réfugiées chin à Delhi en 2012-13. La conceptualisation des "moyens de subsistance» représente un point de départ pour mieux comprendre les expériences de ces femmes concernant le travail, et explorer les risques impliqués qui influent sur leur bien-être. Des données récentes indiquent que l'omniprésence du harcèlement sexuel et de la discrimination, inhérente ainsi qu'extérieure aux divers contextes de travail, associée à un sentiment constant de précarité, entrave gravement à la santé et au bien-être de ces femmes, et contribue à des attentes réduites concernant leur avenir à Delhi.

\section{Introduction}

$\mathrm{R}$ isk permeates all facets of the refugee experience. An individual's decision to flee and seek asylum in another country is informed by risk and uncertainty, while being a risk in itself. ${ }^{1}$ Refugees flee out of a wellfounded fear of being persecuted and the hope that threats and peril will diminish upon arrival in countries of first asylum; however, this may not be the case, as new risks are frequently confronted when durable solutions are sought. For the majority of refugees who have fled to neighbouring countries, a durable solution, such as resettlement to a third country, is never found. As a result, they can either "integrate" into the local host community or repatriate back to their home country. There are 14.4 million refugees of concern to the United Nations High Commissioner for Refugees, ${ }^{2}$ and fewer than 1 per cent will be resettled. This means that, for many refugees, quasi-integration into countries of first asylum will be the only answer.

Refugees from Chin State, Burma, are among the nearly 65.3 million forcibly displaced people worldwide. ${ }^{3}$ The spaces that Chin refugee women have carved for their livelihoods in India - their country of first asylum-have been relatively unexplored. This article adds an important dimension 
to current knowledge by uncovering the rich, lived experiences of the Chin women who engage in or pursue a livelihood specifically in Delhi. Despite the great hardships Chin refugees have faced before and after displacement, they are often ignored in the global media.

This article discusses select findings from a qualitative research project that examined Chin women's well-being and survival in India; we report on emerging findings from Phase 1, which included twenty-eight in-depth interviews with Chin refugee women in Delhi. The primary focus will be Chin women's experiences and their perceptions of the risks they face engaging in or pursuing a livelihood in their country of first asylum.

\section{The Research Context}

Participants originally came from Chin State, a mountainous region of northwestern Burma. Chin State is an agrarian society with an estimated population of 500,000. 4 Since the 1962 military coup, which resulted in the overthrow of the democratic system and the introduction of military rule, ethnic groups from Burma have faced human rights abuses. The Chin face face discrimination that is due not only to their ethnicity, but also their religious identity. They are predominantly Christian in a country where the majority is Buddhist. According to the Chin Refugee Committee, previous military rule resulted in widespread atrocities in Chin State which "led to extrajudicial killings, arbitrary arrest and imprisonment, torture, rape, forced relocation, forced labour, religious persecution, and other violations of basic human rights." Women and girls, especially, lived in fear of rape and other forms of sexual violence as the military used "rape systematically as a means of control, torture and repression." 6 These crimes were often committed with impunity, as military personal were rarely prosecuted and crimes were covered up?

This milieu of violence forced many Chin people to flee to neighbouring India, mainly in the eastern states of Manipur and Mizoram, with hopes of a better life. Despite the recent election of a semi-civilian government in Burma, and a ceasefire declared between the government and armed Chin groups, the militarization of Chin State continues. It is estimated that 75,000-100,000 Chin are living in Manipur and Mizoram, ${ }^{8}$ with an additional 8,ooo in Delhi. ${ }^{9}$

Importantly, India has not ratified the 1951 Convention relating to the Status of Refugees. While refugees in India are not recognized under national legislation, the Indian government has an informal agreement with the United Nations Development Programme (UNDP) to maintain an office in Delhi to register asylum-seekers and provide limited services to refugees living there. Many Chin make the long, expensive trip to Delhi, as it is the only place in India where they can apply for registration. The hope of being resettled to a third country is also a pull factor ${ }^{10}$ that brings refugees to this urban area.

In 2012, the Indian government announced that it would allow registered refugees to apply for long-stay visas, with accompanying work rights. ${ }^{11}$ However, it remains unclear how many long-term visas have actually been granted to Chin refugees. Nevertheless, Chin refugees are still bound to the informal employment sector and work primarily in factories, domestic service, or small-goods sales on the streets. Refugees from Chin State are further disadvantaged because many have limited education and come from agrarian backgrounds, so their skills are not easily transferable to the urban context of Delhi. ${ }^{12}$ They are increasingly at risk of exploitation and discrimination by employers, with refugee women at a heightened risk of sexual and gender-based violence (SGBV). ${ }^{13}$ In fact, there have been widespread reports of SGBV towards Burmese refugee women (at work and in public spaces), which often goes unpunished. ${ }^{14}$

The situation of Chin refugees in India is unique, as they are physically, culturally, and linguistically distinct from the host population. This "otherness" and classification as "refugees" puts them at risk of abuse and harassment from local people. Additionally "their refugee status means they are doubly-disempowered, for they lack the protection of the state, the opportunities for free movement, and the surplus income to escape situations of violence."15

After direct consultation with key informants and refugee women themselves, it became clear that a participatory method of inquiry would be beneficial to explore the topic of livelihood and risk. Indeed, a lack of livelihood creates barriers to meeting several basic needs including health care, education, safe accommodation, and an overall dignified quality of life.

\section{The Conceptual Frameworks of "Livelihood" and "Risk"}

Livelihood

Understanding the influence and effects of livelihood opportunities is essential, as the concept is foundational and used as a platform to explore the complex, fluid, and often dangerous living situations of participants in this study. The bulk of the literature in this area is policy driven, particularly when focused on refugees. In these instances, a livelihood has a functional definition (e.g., a job, the need for food, shelter, etc.). Indeed, the idea of a livelihood is much more than "just a job." According to Gaillard et al., ${ }^{16}$ "Livelihoods rarely refer to a single activity. It includes complex, contextual, diverse and dynamic strategies developed by households to meet their needs." While a livelihood may include money, it also "encompasses in-kind income, social 
institutions (kin, family, and village), gender relations, and property rights required to support and to sustain a given standard of living." 17

Moreover, access to a livelihood is a right for all people, as stated in article 23(1) of the Universal Declaration of Human Rights: ${ }^{18}$ "Everyone has the right to work, to free choice of employment, to just and favourable conditions of work and to protection against unemployment." This right is expanded upon in article 25(1): "Everyone has the right to a standard of living adequate for the health and well-being of himself [sic] and of his [sic] family, including food, clothing, housing and medical care and necessary social services, and the right to security in the event of unemployment, sickness, disability, widowhood, old age or other lack of livelihood in circumstances beyond his control."

The many facets of a livelihood help one achieve a standard of living that is ultimately safe, sustainable, and secure to fulfil other rights with dignity. ${ }^{19}$ At the meso-level, livelihood also includes "access to, and benefits derived from, social and public services provided by the state such as education, health services, roads, and water supplies."2o Therefore, a livelihood is not limited to material wealth, but is also holistic and all-encompassing.

Providing a conceptual framework from which to understand "livelihood" in this article is fundamental, as livelihood experiences are used to delve deeper into participants' overall perceptions of their living situations. More importantly, livelihoods may also be a contributing factor to the risks (or alternatively, a mitigating factor) that refugee women frequently face in countries of first asylum. A "people-centred" approach to livelihoods was appropriate to this research, as it places the reality of Chin women participants at the centre of the analysis, while also considering the relationships between local context and the additional elements of gender, well-being, and structural inequalities experienced in the pursuit of a livelihood.

\section{Risk}

While the prevalence of risks is recognized in migration studies, "there is little explicit theorization of the role of risk ... it is either simply acknowledged or assumed to be implicit in [the act of migrating]. ${ }^{21}$ In fact, there is very limited research on how individuals themselves conceptualize risk more generally in "the broad range of phenomena that have been labeled 'risks."'22 Arguably, the lack of conceptualization in studies on migration is astounding, particularly in relation to refugees, as the entire refugee experience is perilous and full of life-threatening dangers.

Indeed, the literature review reveals that risk is assumed to be entrenched in the refugee experience. However, there is no specific exploration of how the concept of risk and different risk contexts are experienced and perceived in the lives of asylum-seekers and refugees. People encounter risk at all stages of their lives, as risk is "fluid and dynamic over time and space." 23 This personal knowledge of risk "tends to be highly contextual, localized and individualized and reflexively aware of diversity and change ... membership of cultural and social networks and groups is important in the construction and meaning of risk logics." 24 Understanding the context and specific sociocultural factors is imperative to unpacking how Chin refugee women assign meaning to the risks they encounter while pursuing a livelihood in Delhi. Therefore, this project is influenced by a social construction of risk, which views risk as something that "is not a static, objective phenomenon, but is constantly constructed and negotiated as part of the network of social interaction and the formation of meaning." 25 Through phenomenological accounts of risk as provided by the participants in this study, "the 'lived experience,' or how individuals experience their world as an interpretive reality" is best understood. ${ }^{26}$

\section{Literature Review}

Refugees typically leave behind "life-sustaining resources" such as social support networks (like neighbours, friends, and relatives), support services, land, and communities. ${ }^{27}$ For some, "a lack of access to basic needs compounds risk and vulnerability, ${ }^{28}$ and their reaction to such risks or threats is largely dependent on choices available to them. In many urban refugee settings, the choice of options, such as leaving the country or relying on social networks, is limited, ${ }^{29}$ and other obstacles such as discrimination or lack of citizenship rights can occur. Without citizenship, those who are displaced may become susceptible to exploitation or abuse from local people who take advantage of their indeterminate status as asylum-seekers. ${ }^{30}$

The livelihood environment becomes increasingly dangerous when a country is not signatory to the Refugee Convention or Protocol..$^{11}$ Where human rights are not respected and a legal framework to protect refugees is not in place, refugees may find that sustaining a livelihood is difficult and dangerous. Many might depend on remittances from family or friends abroad if such networks exist. ${ }^{22}$ They may struggle "due to an absence of civil, social and economic rights including freedom of movement and residence, freedom of speech and assembly, fair trial, property rights, the right to engage in wage labour." 33 As workers in the informal employment sector, they may be underpaid and exploited by their employers.

The "gendered nature of risk" is important when looking at the identifiable dangers women encounter ${ }^{34}$ as they pursue livelihoods. Risk analysts argue that men and women perceive risk differently. ${ }^{35}$ Yet the majority of risk-related 
and risk-theory research tends to ignore the gendered nature of risk perception and focuses mainly on "abstract universal and gender neutral subjects." 36 Livelihood experiences of men and women in both rural and urban areas are diverse and dynamic; however, for women specifically, experiences involve "transformative struggles through which they work to empower themselves by reshaping their identities, lives and relationships within households and communities." 37 While there is a plethora of literature on livelihood activities, particularly in rural areas, what is missing is rich data on "the role played by gender and generation in influencing differential access and ability to command resources on the part of individual household members. ${ }^{38}$ It is still assumed that context directly affects women's choices (and limitations) in the way they secure a livelihood, highlighting the distinct and personal approach to livelihood. However, a cross-cutting theme that highlights agency is that women are also "actively making decisions regarding how best to meet their own needs and those of their families." 39

Research on the topic of refugee women's livelihoods and risk in urban areas is lacking, and "there is a poor understanding of, and relatively few studies on, how the safety of urban refugee women can be compromised by going out to work." 40 For refugee women, SGBV is heightened during conflict and displacement, particularly when work rights are lacking. ${ }^{41}$ Consequently, refugees are forced to find a job that "presents the risk of exploitation and serious protection problems ... [Women in particular] are susceptible to the dangers of working in the streets without protection against theft, rape, sexual abuse, exploitation or unhealthy physical environments." 42 This lack of economic opportunity may also result in high-risk activities such as "survival sex."43

Importantly, women with children often "carry a double burden of reproductive and productive duties" as they balance paid work with childrearing obligations. ${ }^{44}$ Some refugee women may take on the primary role of provider and wage earner and carry the responsibility to provide for their family. 45 In displacement contexts, they might be playing a more prominent role in the workforce if the men are "absent, disabled or unwilling to do the lower status and lower paid jobs that are available." 46 As such, men and women experience the livelihood environments, and the risks and strategies involved, differently, and this is why the research was undertaken solely with women.

\section{Methodology}

The researcher (first author) conducted twenty-eight indepth interviews with Chin refugee women in Vikaspuri, in the western part of Delhi, in 2012 and 2013. Participants were recruited using a snowball sampling technique. Interviews took place at the home of a Chin refugee woman who ran a well-regarded women's rights organisation. The identity of the organization and the woman have deliberately been kept anonymous to protect them from harassment. The participants felt secure travelling to this location, as it did not attract unwanted attention from local people; the location was comfortable and familiar for both participants and researcher. During the interviews, a translator was present who was fluent in two Burmese dialects and English.

The interviews were semi-structured, commencing with the collection of basic demographic information such as age, marital status, how long they had lived in Delhi, and number of family members. Participants then provided information on employment opportunities in Chin State and then in Delhi, highlighting associated risks and the daily struggles experienced. The emergent area of livelihood risk usually led to a broader discussion of risk for refugee women in Delhi more generally. Finally, participants discussed the role of social support and coping mechanisms used when facing hardship. While the interviews were semi-structured, they remained sufficiently open-ended for participants to provide greater detail on different aspects of their lives (for example, health or housing problems) if needed.

Constructivist grounded theory, which is an inductive and emergent process, was used in this research project. A grounded methodological approach uses "systematic inductive guidelines for collecting and analyzing data to build middle-range theoretical frameworks that explain the collective data." 47 This analytical method was chosen because, as Stern notes, grounded theory is particularly relevant in "investigations of relatively uncharted water." 48 This approach was deemed most appropriate, as little is known about the context of risk in relation to the livelihoods of Chin refugee women in Delhi. Constructivist grounded theory is also useful in "understanding and explaining human experience as it is lived." 49 The experiences of Chin women are necessarily subjective and contextually defined, which is exactly what this project sought to uncover.

Data collection and analysis were carried out simultaneously, with the approach shifting as the study progressed. Transcription and coding began immediately after the indepth interviews were completed. Comparative methods were used throughout the analysis, along with memo-writing and theoretical sampling. Through constant comparative analysis, "grounded theorists compare data with data, data with codes, codes with codes, codes with categories, and their finished analyses with relevant theoretical and research literatures."50

Participants have experienced trauma, along with severe hardships. As such, careful consideration of an ethical research process was paramount throughout the project. The study received approval from the Human Research 
Ethics Committee (HREC) of the University of New South Wales (HREC Approval HC12280), Australia. A strict code of ethics was adhered to, which ensured that participants were treated with dignity and respect. Additionally, a counselling referral service was identified in Delhi in the event that participants became distressed during or as a result of the interviews.

\section{Preliminary Findings}

Participants were aged between eighteen and fifty-fve. Marital status highlights several widows, who of necessity become sole earners in their household. Four main employment areas were identified by the Chin women: waitresses at Indian wedding parties; domestic staff in households of Korean families; company (i.e., factory) workers; and, selfemployed or "other." All four employment areas are in the informal sector, which means they are unregulated, with salary paid cash in hand. In addition, work was irregular and many women reported changing jobs to best survive. For instance, the majority of participants have worked in two to three of the listed occupations and were therefore able to share insights from more than one job. Participants' demographic characteristics are summarized in table 1.

Participants disclosed that all employment areas involved some personal risk. However, any problems or complaints experienced by Chin women were typically not addressed, or even reported to employers, because the women were fearful that such actions could result in negative repercussions to themselves and their family. Consequently, many participants reported feeling they had no choice but to accept and endure any job offered.

The following discussion provides a summary of women's reported experiences of the four emergent employment areas and participants' perceptions of the risks involved when negotiating these occupations. This section offers a discussion of the overall themes emerging from the coding and analysis of the textual data. This stage of analysis, or "focused coding," occurred early in the grounded research process and, as such, the results presented here are more abstract but will contribute significantly to the final conclusions of this ongoing study.

\section{Findings}

\section{Indian Wedding Parties}

The "wedding season" in India typically runs from September to January. Many participants felt that waitressing at wedding parties was the most dangerous occupation for refugee women in Delhi. However, this job paid quite well compared to other alternatives. For instance, a woman could receive up to Rs40o-50o (US\$6-8) per party, whereas one day of work at a company would earn only Rs125-180
Table 1. Participants' demographic features

\begin{tabular}{lr} 
Number of interviews & 28 \\
Age range & 185 \\
Average number of years living in Delhi & 3.3 \\
Marital status & 6 \\
Single & 10 \\
Married & 10 \\
Widow & 2 \\
Unknown & \\
Employment & 4 \\
Wedding party & 11 \\
Company & 4 \\
Korean house & 4 \\
Self-employed & 5 \\
Other & 12 \\
Sole income earner in the household & \\
\hline
\end{tabular}

(US\$2-2.90)..$^{51}$ Reported risks included being propositioned for sex and being sexually harassed and groped:

There [wedding party] is not safe at all. Some of the local men are very bad, all the time. It is very dangerous for us. They touch our face, they touch our bottoms and they pull at our dresses. They say bad things to us, and I have seen them grope my friends. It's not safe. I don't have enough strength to work at the wedding party anymore and also I am scared to work there. (W5)

The grooms, the guests, some of them get drunk and for the girls it's not safe that late at night. And they call to us, "How much?"... they want something sexual. $\left(\mathrm{W}_{7}\right)$

Most women took this job only if they were more desperate for money than usual, perhaps as the result of frequent illness in their household or if they were sole income earners. Many spoke of the humiliation involved with this work:

If a man touches me at the wedding party, the other guests laugh at me. They laugh at me and I feel very shy and upset, but I have no choice but to work there. There are other jobs around here, but the pay is much less. So, if they phone me, I have to work for the survival of my family. I have no choice. (W3)

When women were sexually harassed, they could not complain, because employers were not present or remained indifferent:

When we are harassed or they ask something sexual, we just ignore the men and tell them we are not like that. We just keep 
doing our job because there is no other option. Most of the men usually go away. (W2)

However, a few of the women would fight back when provoked:

When the men grab our bodies, some of them I slap, like this [motions with her hand], sometime from my mouth I shout for them to go away. (W3)

When the men ask, "How much?" we reply, "We come for work, we are not like that." ( $\left.\mathrm{W}_{7}\right)$

Most women ${ }^{2}$ found out about wedding party jobs through friends or a "recruiter." For example, a Burmese man working for an Indian employer served as the "contact" to recruit women to work at weddings. The women were specifically told to wear short skirts and revealing clothing. The job typically started around 6 p.m. (but sometimes earlier) and ended around 2 or 3 a.m. Depending on the location, the women were picked up by a rented bus and taken to the venue, then also taken home. Some women reported that this time of night could be dangerous because sometimes they were locked out of their homes by landlords; the women waited on the street until 6 a.m. or went to a friend's house if possible. The risks associated with this job were great, but often there was no alternative and the women had to stay on. This was the case for one woman who, along with her husband, was supporting two children and a disabled brother:

I am searching for another job at the company also, but till today I can't find a job. I have no choice. If there is a wedding party, then I will work again. (W7)

\section{Domestic Staff at Korean Households}

A number of Korean families in the Delhi outskirts and Noida (southeast of New Delhi) employed Chin refugee women as housekeepers. Participants claimed that Korean families preferred to hire the Chin because of perceived commonalities in appearance. Many Korean expatriates were working for Korean technological companies, or setting up Korean restaurants or guesthouses.

The job of housekeeper included cooking, cleaning, and minding children in the households. These jobs were typically arranged through word-of-mouth from friends. Single, unaccompanied women preferred jobs at Korean households because they were provided with room and board:

I don't have very close family here or relatives, so when I work in a Korean house I get more than I would get at a different job. Also, the Korean family gives me food and shelter. (W2)
They could live with friends and find a different job but did not want to be dependent on people who were not family members, as every family, in their words, had their own problems:

Sometimes we help each other, but as you know, everyone, every household is facing these problems in finances, so sometimes you can't get help ... or we don't trust each other. (W13)

In the Korean house we get a room, a separate room and our own life. (W2)

Sexual harassment occurred at Korean households, not usually by the employer, but by other employees of the house (e.g., the driver or security person). Two women recounted how they had to barricade themselves in their room because another employee was trying to get in "and harass us." One woman mentioned that an Indian worker propositioned her for sex at her house. The women always kept their doors shut and told the men to go away. Another woman experienced sexual harassment from the family driver (who was Indian); the man tried to touch her and say "something about sex." She complained to her employer, but the employer only scolded her.

If I face these kinds of problem again [sexual harassment] I will be looking for another job. It's a cycle. I have worked at so many Korean houses and at every house I have been harassed. (W2)

While harassment is common, it is often ignored:

We just ignore them and keep doing our job because there is no other option. (W2)

The women reported that Korean employers did not usually harass them; however, they offered little to no protection if other workers sexually harassed the women. Working hours were often set from 6 a.m. until 6 p.m., but the women were on call twenty-four hours a day and could be summoned at any time. The employer was usually a female head of household. If she got angry or upset with a Chin woman employee, she would withhold food, as reported by all women who worked in Korean households. Despite the risks faced in such workplaces, many women felt that they were safer and had marginally better conditions than Indian wedding parties.

\section{Company Work}

Company jobs involved the manufacture of a variety of goods (such as clothing or toys). Participants reported that the companies were often located in one room with poor 
ventilation and lighting, and hours of employment were very long. Despite the severe risks involved, a few women felt that company jobs were a safer option when compared to the alternatives.

Because work hours are long, some women noted that their children had to stay home alone after school (if they were enrolled) while they were at work. One woman locked her children in their room because the neighbourhood was not safe and she feared for them when they ventured outside alone. As one widow who worked at a company described her experience working in Delhi,

My children are at a church-run school from 8 a.m. to 11 a.m. After that they come home alone. They are six, nine, and twelve years old. I finish work at 6 p.m. After the school day they come home on their own and they stay on their own at the house ... I don't have time to take care of them and look after them. It's very difficult [starts to cry]. As a mother, I can't see the future. For my children, there is no future at all to see if we stay here in Delhi. Still, we can't do anything ... We can't leave, we can't get resettlement, so ... it is very difficult to stay in Delhi. (W28)

According to another woman, also a widow, sexual risks were prevalent in companies:

It's not safe; it's not safe to work there, but if we don't work there we don't have anything to eat ... it's very difficult to find other jobs at other companies because I am forty-four years. One of my co-workers, a local man, asked me to sleep with him and he would give me Rs50o ... I was very angry and I said to him, "Do you think I'm a prostitute?" I was angry. Sometimes if a woman is beautiful, they ask for Rs10oo or more [for sex]. The girls are not safe. I have stayed here in Delhi since 2008 and I have heard lots of stories about this [girls being propositioned for sex]. Some women used to talk about their daughters who are experiencing harassment from the company. I have heard lots of stories like that. The refugee women, girls face lots of harassment and abuse in their working place. Some girls, the pretty or smart ones, they are asked how much [for sex]. (W25)

At some companies, local people were often paid more than refugee women, even though they were doing the same job. The women were also harassed and verbally abused by other local workers. They could not complain to employers, as they did not speak Hindi:

They [local people] look down on us because we are refugees and we are different from them. Our skin is different. If we are working, the co-workers, the local people, tell us what to do. Tell us to do our work. We are working, we are doing our work, but still they tell us what to do. (W28)
Despite the risks, a few participants preferred this type of job, but only when they had a good employer. According to them, a good employer would employ them again when they had to leave as the result of illness, or stood up for them if they were harassed. While rare within this context, two participants spoke of having come across decent employers.

\section{Self-employed and "Other"}

The women who identified as self-employed or "other" mainly sold small goods on the streets of Delhi, provided basic services to neighbours, such as doing laundry, or worked myriad other jobs. Participants described selfemployment as desirable, but this type of work also had its share of risks.

Working outside of recognized employment contexts was dangerous. For example, selling goods on the street rendered women vulnerable, as local men would often deliberately target women, groping them in public or making inappropriate sexual remarks. However, this behaviour was not limited to women who worked on the street. Every woman in this study reported this as a common, sometimes daily occurrence in public spaces.

Those who classified their work as "other" worked myriad jobs because they continued to be harassed in the employment contexts described above. One thirty-three-year-old single woman spoke of the hardships she faced while working in Delhi:

Thinking about my past, I'm not so happy. One time I was walking home from work and there was a man on a bike coming toward me. He was following me. I was just walking and then he came and turned around to me. He touched my breasts twice. And I was crying, crying, and I just try to follow the bike, to chase him, but the bike is at full speed and he got away. I was crying, crying ... I have also had my purse stolen twice. Both times on payday (and on the bus). Perhaps this was planned? I used to have one boss who I thought I could trust, but he turned out to be bad. He tried to take advantage of me when he gave me a lift home. So there are many problems for refugees. Women cannot eat good food, so we don't have much energy. Our minds, everything is weak, weakened. Always depressing. (W20)

Another participant mentioned being robbed on payday, which brought up the question of whether this was an organized scheme rather than random misadventure.

Earnings for those who were self-employed were very low (much like the other occupations) and sometimes the women's children had to work to make ends meet. One participant who sold cigarettes and pickles in her neighbourhood, told of her thirteen-year-old son who worked parttime because her husband was too sick to work: 
My son goes to school when we can afford it, but when we are facing a severe crisis, he has to work. He sometimes works two to three days a week for up to twelve hours a day. He works in the District Centre selling tea. We are scared we can't pay the house rent, so that's why, at the time when we face that severe financial problem, my son has to work too. (W10)

A common theme was that work in this context was infrequent, which meant that they were trapped and obligated to put up with abusive and dangerous situations. This is why many of the women had aspirations to run their own income-generating activities, where they could work from home or with other Chin women because, as one woman said with an ironic laugh, "The only safe job [in Delhi] is doing housework at home!"

\section{Discussion}

As De Haan argues, "Livelihood activities are not neutral. They engender processes of inclusion and exclusion and power is part of that." 53 This is indeed exemplified in the reported experiences of participating Chin refugee women in Delhi. While there were economic opportunities for these women that should have mitigated select risks. However, these livelihood opportunities also involved considerable personal risk, primarily sexual harassment and other forms of SGBV. Participants then faced additional obstacles when trying to sustain economic livelihood opportunities, such as not speaking the local language and constant experiences of discrimination. The women reported encountering SGBV and sexual harassment primarily by local Indian men. Moreover, Chin women were easily targeted because "they looked different" from the local people, and because of their gender and refugee status.

Participants could not engage in work in the formal employment sector, which "limits their control over their lives and livelihoods." 54 It became evident that engaging in and maintaining in the informal sector exposed the women to serious dangers. For example, a young woman could easily find a job in a Korean household, but her freedom of movement was restricted. She may experience harassment from local employees and her wages and provision of food depended on the mood or demeanour of her employer. The Chin refugee women had no bargaining power in these situations because they were "outsiders." As one participant said,

They look down on us because we are refugees and we are different from them ... our skin is different. (W28)

They experienced "unfavourable inclusion": 55 Chin refugee women were not being excluded from pursuing a livelihood; they were included, but under severely unfavourable and unsustainable conditions. These unfavourable conditions were not limited to the employment context; in fact, the women and their families were "unfavourably included" in education, housing, and health. These conditions left them feeling disempowered. As one widow with two children said,

It's not safe here. It's not safe to work here ... but we can't go home to Burma and we can't go to other countries. We are stuck here in Delhi. (W25)

The women felt that they had no choice but to put up with adverse and dangerous conditions because work options were so limited. In Delhi, personal agency was compromised by the influence of factors such as gender, which inhibited their capacity to pursue safe livelihoods and self-reliance. According to the participants, free choice when negotiating a livelihood simply did not exist; they kept reiterating that they had no choices available to them in Delhi. In the majority of cases, they had to take what was offered because they were so desperate for any income. Many women had skills from their previous lives in Burma that they would have liked to use, but the opportunities were just not available:

I feel sad and depressed. I am just a housemaid. In Myanmar I am a student of the college. In India I am just a housemaid. (W4)

This lack of choice, combined with a living context where harassment and abuse were handed out without consequence, created a dangerous environment where they were allowed to pursue work, but inevitably, risk was embedded in it. This is not to say that they did not exhibit any personal agency or resilience. Some of their decisions were made independently and were strategic, but they were often choosing the least damaging option from a number of poor opportunities.

According to Chan and Rigakos, ${ }^{56}$ the nature of risk is different for women and is inherently gendered. The present discussion suggests that the risks encountered by participants in the livelihood context were overwhelmingly about sexual violations of their bodies. This is consistent with earlier research undertaken with Burmese refugee women in Delhi..$^{57}$ In this current project, participants' knowledge of risk was highly localized and influenced by gender and was unique to these Chin refugee women. In their minds, the actual risk (SGBV) was tangible but could be understood and explained only subjectively. The results indicate that risk perception, while subjective, is also influenced by sociocultural constructs. The participants' meanings of risk were "constructed" through cultural or social practice: (1) through direct, personal experiences in Delhi and through interactions with the local people, and (2) through discourse and knowledge creation with other Chin refugee women. 
Additionally, to fully understand how participants themselves identified these risks (and responded to them), consideration must be given to the influence of gender, refugee status, Chin ethnicity, and their overall experiences (past and present) in the asylum cycle. To many participants, the risk of SGBV highlighted the power imbalance between them and local men who preyed on them, not only because of their gender, but because they were aware of their vulnerable status as refugees. They could exploit and take advantage of these women because they knew they could get away without fear of punishment.

Frequent SGBV had broken the will of many participants. Other issues such as rape and survival sex were also prominent in the data (forthcoming). Many participants reported that these experiences were detrimental to the mental health (and in some instances, the will to live), with depression and a sense of hopelessness a common theme in all interviews:

"I want my freedom to stay and work on my own. We people have different interests and skills, but we can't use these interests. We can't do anything, so we are stuck here and we are depressed and our young children ... I can't imagine how the future will be for them. (W25)

Sometimes I feel like dying or something ... but if I die, who will take care of my children? So I have lots of depression and sometimes I feel like I'm nothing to my children. I feel something like that. (W14)

The findings outlined here also open up a wider discussion on the concept of livelihood. In Delhi, a livelihood involved much more than the mere materialistic notion of finding and maintaining paid work; while inclusive of basic needs, it also encompassed the participants' identity and sense of worth, and connectedness to community and family. Pursuing and engaging in a livelihood was interconnected with other facets of their lives. For example, when they were not working, some participants had to choose between using their meagre resources to send a child to school or pay rent. In more severe cases, it was choosing between food and rent. Even when participants were employed, the repercussions of these unsafe livelihoods could be felt, primarily in relation to the women's mental health.

The findings also suggest that the concept of livelihood should include an optimal achievement of rights and personal well-being underpinned by a safe work environment and reduced vulnerability. This approach is aligned with the conceptual thinking and work of earlier researchers. ${ }^{8}$ The Chin women indicated that they had yet to achieve an adequate standard of living or quality of life in Delhi. Additionally, because of the inequalities they experienced, an adequate standard of living could not be met within this context. Participants were excluded from accessing basic resources and safe livelihoods and were increasingly vulnerable to risk and discrimination due to intersecting factors such as gender and their status as "outsiders."

\section{Conclusion}

The emergent findings outlined here can be used to guide future economic initiatives for refugee women in Delhi, to include built-in strategies and mechanisms to mitigate risk. Greater insights into these women's experiences of livelihood risks can lead to increased awareness, support, and advocacy for Chin refugees living in India. Chin refugees have fled persecution, torture, and sexual violence from the Burmese military junta in the hope of finding a safe and accommodating environment in Delhi; however, their reality seems to suggest the opposite. They face severe discrimination, pervasive SGBV, and lack of safe jobs and housing. Clearly, this lack of safe livelihoods, and an all-encompassing context of risk, will continue to hinder any goal of selfreliance. Chin women continue to be marginalized and their voices are being silenced. While their strength is something to admire, their perpetual suffering is devastating.

The refugees are hopeless. We are hopeless; we are stuck here in Delhi. (W12)

\section{Notes}

1 Allan M. Williams and Vladimir Baláž, "Migration, Risk, and Uncertainty: Theoretical Perspectives," Population, Space and Place 18, no. 2 (2012): 167-80.

2 United Nations High Commissioner for Refugees, "Resettlement," http://www.unhcr.org/resettlement.html.

3 United Nations High Commissioner for Refugees, "Figures at a Glance: Global Trends 2015," http://www.unhcr .org/figures-at-a-glance.html.

4 Human Rights Watch, “We are like forgotten people': The Chin People of Burma: Unsafe in Burma, Unprotected in India," New York, 2009, 1-99.

6 Other Media, Battling to Survive: A Study of Burmese Asylum-seekers and Refugees in Delhi (Bangalore: Other Media Communications, 2010), 12.

7 Women's League of Chinland, Unsafe State: State-Sanctioned Sexual Violence against Chin Women in Burma (Mizoram, India: Women's League of Chinland, 2007), $1-38$.

8 Human Rights Watch, "We are like forgotten people."

9 The Chin make up the majority of Burmese refugees in Delhi. While there are a small percentage of Burmese from other ethnic groups, this study was undertaken solely with Chin refugees. See also Jayashree Nandi, "Burmese Refugees Demand a Life in Delhi," Times of India, 16 
October 2014, http://timesofindia.indiatimes.com/city/ delhi/Burmese-refugees-demand-a-life-in-Delhi/articleshow $/ 44831815 . \mathrm{cms}$.

10 Karen Jacobsen, "Refugees and Asylum-seekers in Urban Areas: A Livelihoods Perspective," Journal of Refugee Studies 19, no. 3 (2006), 273-86.

11 Linda Bartolomei, "6 Surviving the City," Urban Refugees: Challenges in Protection, Services and Policy, Koichi Koizumi and Gerhard Hoffstaedter (London: Routledge, 2015), 140.

12 Women's Refugee Commission, "Peril or Protection: The Link between Livelihoods and Gender-Based Violence in Displacement Settings," https://www.womensrefugeecommission.org/peril-or-protection-making-work-safe.

13 According to UNHCR, sexual and gender-based violence (sGBV) refers to any act that is perpetrated against a person's will and is based on gender norms and unequal power relationships. It encompasses threats of violence and coercion. It can be physical, emotional, psychological, or sexual, and can take the form of a denial of resources or access to services. UNHCR, "Sexual and Gender-Based Violence," http://www.unhcr.org/sexual-and-gender-based-violence .html See also Bartolomei, "6 Surviving the City"; Dale Buscher, "New Approaches to Urban Refugee Livelihoods," Refuge: Canada's Journal on Refugees 28, no. 2 (2013): 17-29; Joint IDP Profiling Service, Urban Profiling of Refugee Situations in Delhi (Geneva: Joint IDP Profiling Service, 2013), 1-86; Jesuit Refugee Service, Chin Refugees in Delhi: Realities and Challenges (New Delhi: Jesuit Refugee Service, 2013), 1-76.

14 Chin Human Rights Organization, Waiting on the Margins: An Assessment of the Situation of the Chin Community in Delhi, India (New Delhi: CHro, 2009), 1-33; Centre for Refugee Research, Looking Forward: A Report from Community Consultations November 2007, New Delhi, India (Sydney: University of New South Wales, 2007), 1-47. 15 Bartolomei, "6 Surviving the City," 152.

16 Jean-Christophe Gaillard, Emmanuel A. Maceda, Elodie Stasiak, Iwan Le Berre, and Maria Victoria O Espaldon, "Sustainable Livelihoods and People's Vulnerability in the Face of Coastal Hazards," Journal of Coastal Conservation 13, nos. 2-3 (2009): 121.

17 Frank Ellis, "Household Strategies and Rural Livelihood Diversification," Journal of Development Studies 35, no. 1 (1998): 4 .

18 un General Assembly, Universal Declaration of Human Rights (1948).

19 Programme on Women's Economic Social and Cultural Rights, "Locating Women's Livelihoods in the Human Rights Framework," discussion paper (New Delhi: Social and Cultural Rights Programme on Women's Economic, Social, and Cultural Rights, 2011), 1-12.

20 Ellis, "Household Strategies," 4.

21 Williams and Baláž, "Migration, Risk, and Uncertainty," 168.
22 Jens O. Zinn, "Risk as Discourse: Interdisciplinary Perspectives," Critical Approaches to Discourse Analysis across Disciplines 4, no. 2 (2010): 20.

23 Deborah Lupton, "Sociology and Risk," Beyond the Risk Society: Critical Reflections on Risk and Human Security, ed. Gabe Mythen and Sandra Walklate (Berkshire: Open University Press, 2006), 21.

24 Deborah Lupton and John Tulloch, "'Risk Is Part of Your Life': Risk Epistemologies among a Group of Australians," Sociology 36, no. 2 (2002): 319.

25 Deborah Lupton, Risk (Wiley Online Library, 1998), 29, https://books.google.co.in/books/about/Risk.html?id= YPG5ADCaOGIC.

26 Ibid., 27.

27 Gaim Kibreab, “Displacement, Host Governments' Policies, and Constraints on the Construction of Sustainable Livelihoods," International Social Science Journal 55, no. 175 (2003): 57.

28 Eileen Pittaway, Making Mainstreaming a Reality: Gender and the Unhcr Policy on Refugee Protection and Solutions in Urban Areas (Sydney: Centre for Refugee Research, 2010), 3 .

29 Susanne Jaspars and Sorcha O'Callaghan, "Challenging Choices: Protection and Livelihoods in Conflict," Policy Brief 40, Humanitarian Policy Group, 2010.

30 Pittaway, "Making Mainstreaming a Reality."

31 Human Rights Watch, "We are like forgotten people"; Machtelt De Vriese, "Refugee Livelihoods: A Review of the Evidence," United Nations High Commission for Refugees, 2006, http://www.unhcr.org/4423fe5d2.html.

32 Karen Jacobsen, "Livelihoods in Conflict: The Pursuit of Livelihoods by Refugees and the Impact on the Human Security of Host Communities," International Migration 40, no. 5 (2002): 95-123.

33 Ibid., 101.

34 Teela Sanders, "A Continuum of Risk? The Management of Health, Physical and Emotional Risks by Female Sex Workers," Sociology of Health and Illness 26, no. 5 (2004): 558 .

35 Wendy Chan and George S. Rigakos, "Risk, Crime and Gender," British Journal of Criminology 42, no. 4 (2002): 743-61.

36 Kelly Hannah-Moffat and Pat O'Malley, eds., Gendered Risks (London: Taylor \& Francis, 2007), 2.

37 Ann M. Oberhauser, Jennifer L. Mandel, and Holly M. Hapke, "Gendered Livelihoods in Diverse Global Contexts: An Introduction," Gender, Place \& Culture 11, no. 2 (2004): 206.

38 Ibid.; Jo Beall, "Living in the Present, Investing in the Future: Household Security among the Urban Poor," in Urban Livelihoods: A People-Centred Approach to Reducing Poverty, ed. Tony Lloyd-Jones, 71-87 (London: Earthscan, 2002).

39 Oberhauser, Mandel, and Hapke, "Gendered Livelihoods.” 
40 Jeff Crisp, Tim Morris, and Hilde Refstie, "Displacement in Urban Areas: New Challenges, New Partnerships," Disasters 36 (2012): S3O.

41 Women's Refugee Commission, Peril or Protection.

42 De Vriese, "Refugee Livelihoods," 17.

43 United Nations High Commissioner for Refugees, "Refugee Livelihoods in Urban Settings," 2012, http://www .unhcr.org/4boco3589.pdf.

44 Anke Niehof, "The Significance of Diversification for Rural Livelihood Systems," Food Policy 29, no. 4 (2004): 331.

45 De Vriese, "Refugee Livelihoods."

46 Ibid., 22, citing Leben Nelson Moro, "Livelihood Opportunities for Sudanese Refugees," Forced Migration Review 1, no. 20 (2004).

47 Kathy Charmaz, "Grounded Theory: Objectivist and Constructivist Methods." In Strategies of Qualitative Inquiry, ed. N. K. Denzin and S. Lincoln (Thousand Oaks, CA: Sage, 2003), 249.

48 Phyllis Noerager Stern, "Grounded Theory Methodology: Its Uses and Processes," Image 12, no. 1 (1980): 20.

49 Phyllis Noerager Stern and Sue Holland Pyles, "Using Grounded Theory Methodology to Study Women's Culturally Based Decisions about Health," Health Care for Women International 6, nos. 1-3 (1985): 3.

50 Kathy Charmaz, "The Power and Potential of Grounded Theory," Medical Sociology Online 6, no. 3 (2012): 4.

51 The average monthly rent for Chin refugees in Delhi is Rs4,000-5,500 (Us\$64-88), so the wages earned in the jobs listed are not enough to survive, particularly if there is only one earner in a household.

52 Burmese men can also get jobs at Indian wedding parties, but it is rare for the men and women to work at the same wedding at the same time.
53 Leo J. De Haan, "The Livelihood Approach: A Critical Exploration," Erdkunde 66, no. 4 (2012): 349.

54 Paula Kantor, "Women's Exclusion and Unfavorable Inclusion in Informal Employment in Lucknow, India: Barriers to Voice and Livelihood Security," World Development 37, no. 1 (2009): 195.

55 Amartya Kumar Sen, Social Exclusion: Concept, Application, and Scrutiny (Manila: Office of Environment and Social Development, Asian Development Bank, 2000).

56 Chan and Rigakos, "Risk, Crime and Gender."

57 Chin Refugee Committee, Lives of Chin Refugees in Delhi; Buscher, "New Approaches to Urban Refugee Livelihoods"; Bartolomei, "6 Surviving the City."

58 Jacobsen, "Refugees and Asylum-seekers"; De Vriese, "Refugee Livelihoods"; Programme on Women's Economic Social and Cultural Rights, "Locating Women's Livelihoods."

Paula Jops is a PhD candidate in the School of Social Sciences at University of New South Wales Australia. The author may be contacted atp.jops@unsw.edu.au.

Caroline Lenette is a lecturer in the School of Social Sciences and affiliated with the Forced Migration Research Network (FMRN@UNsw), University of New South Wales Australia. The author may be contacted at c.lenette@unsw.edu.au.

Jan Breckenridge is an associate professor in the School of Social Sciences at University of New South Wales Australia and the co-convener of the UNSW Gendered Violence Research Network. The author may be contacted at j.breckenridge@ unsw.edu.au.

(C) Paula Jops, Caroline Lenette and Jan Breckenridge, 2016. This open-access work is licensed under a Creative Commons AttributionNonCommercial 4.0 International License, which permits use, reproduction and distribution in any medium for non-commercial purposes, provided the original author(s) are credited and the original publication in Refuge: Canada's Journal on Refugees is cited. 